This is an Accepted Manuscript of an article published by Taylor \& Francis Group in Journal of Environmental Economics and Policy on 11 Jun 2019, available online:

http://www.tandfonline.com/10.1080/21606544.2019.1623083.

\title{
Economic valuation of ecosystem goods and services: a review for decision makers
}

Dr Robert Tinch ${ }^{1 *}$, Dr Nicola Beamont ${ }^{2}$, Tim Sunderland ${ }^{3}$, Ece Ozdemiroglu ${ }^{4}$, David Barton ${ }^{5}$, Dr Colm Bowe ${ }^{6}$, Tobias Börger ${ }^{7}$, Dr Paul Burgess ${ }^{8}$, Canon Nigel Cooper ${ }^{9}$, Dr Michela Faccioli $^{10}$, Prof Pierre Failler ${ }^{11}$, Ioanna Gkolemi ${ }^{12}$, Dr Ritesh Kumar ${ }^{13}$, Prof Alberto Longo ${ }^{14}$, Alistair McVittie ${ }^{15}$, Prof Joe Morris ${ }^{16}$, Prof Jacob Park ${ }^{17}$, Prof Neil Ravenscroft ${ }^{18}$, Marije Schaafsma $^{19}$, James Vause ${ }^{20}$, Dr Guy Ziv ${ }^{21}$

1*: Director, Iodine sprl, Chaussée de la Hulpe 425, Brussels B-1170, Belgium. robtinch@gmail.com

2: Environmental Economist, Plymouth Marine Laboratory, Prospect Place, Plymouth, UK, PL1 3DH, UK, nijb@pml.ac.uk

3: Principal Specialist Economics, Natural England, Foss House, Kings Pool, 1-2 Peasholme Green, York YO1 7PX, Tim.Sunderland@ naturalengland.org.uk

4: Director, eftec, 4 City Road, London EC1Y 2AA, UK ece@eftec.co.uk

5: Senior Research Scientist, Norwegian Institute for Nature Research (NINA), Gaustadalleen 21, 0349 Oslo, Norway. david.barton@nina.no

6: Senior Lecturer in Environmental Science, Liverpool John Moores University, Liverpool L3 3AF, UK. c.bowe@ljmu.ac.uk

7: University of Stirling, Economics Division, Stirling, FK9 4LA, UK. tobias.borger@stir.ac.uk

8: Reader in Crop Ecology and Management, Cranfield Soil and Agrifood Institute, School of Water, Energy and Environment, Building 52a, Cranfield University, Cranfield, Bedfordshire, MK43 0AL, UK. P.Burgess@ cranfield.ac.uk

9: University Chaplain, Anglia Ruskin University, East Road, Cambridge CB1 1PT, UK; and The Diocese of Ely, Bishop Woodford House, Barton Road, Ely, CB7 4DX, UK. nigel.cooper@anglia.ac.uk

10: Affiliation at the time of contributing to the paper: Social, Economic and Geographical Sciences Research Group, The James Hutton Institute, Aberdeen AB15 8QH, UK and current affiliation: Land, Environment, Economics and Policy (LEEP) Institute, University of Exeter Business School, Xfi Building (1st floor), Rennes Drive, Exeter EX4 4PU, UK. $\underline{\text { m.faccioli@exeter.ac.uk }}$ 
11: Professor of Economics, Economics and Finance Group, Centre for Blue Governance, Portsmouth Business School, University of Portsmouth, Richmond Building, Portland Street, Portsmouth, PO1 3DE, UK. Pierre.failler@port.ac.uk

12: Independent economist, Nemertis Ltd., 14 Fitzroy House, Longfield Avenue, Ealing, London W5 2JG, UK. ioanna.gkolemi@ nemertis.com

13: Professor in Agri-food and environmental economics, School of Biological Sciences, Gibson Institute, IGFS, Queen's University Belfast, Belfast, UK. a.longo@qub.ac.uk

14: Conservation Programme Manager, Wetlands International South Asia, A-25, Defence Colony, New Delhi - 110024, INDIA. ritesh.kumar@wi-sa.org

15: Ecosystem Services Economist, SRUC, West Mains Road, Edinburgh EH9 3JG, UK. alistair.mcvittie@sruc.ac.uk

16: Emeritus Professor, Cranfield University, Bedford, MK43 0AL, UK. j.morris@cranfield.ac.uk

17: Professor of Strategy, Innovation, and Entrepreneurship, Green Mountain College, One Brennan Circle, Poultney, VT, 0576, USA.parkj@greenmtn.edu

18: Head of School of Real Estate and Land Management Royal Agricultural University Cirencester Gloucestershire GL7 6JS, UK. neil.ravenscroft@rau.ac.uk

19: Lecturer (Assistant Professor), School of Geography \& Environmental Science, University of Southampton, University Drive, Southampton SO17 1BJ, UK M.Schaafsma@ soton.ac.uk

20: Lead Economist, UN Environment World Conservation Monitoring Centre, 219 Huntingdon Road, Cambridge CB3 0DL, james.vause@ unep-wcmc.org

21: Associate Professor in Ecosystem Services, Woodhouse Lane, School of Geography, University of Leeds, LS2 9JT, UK. G.Ziv@leeds.ac.uk

*: author for correspondence

\section{Acknowledgements:}

Dr Tinch has been supported by funding from the European Union's Horizon 2020 research and innovation programme under grant agreement No 678760 (ATLAS). This article first started life as a review paper for Valuing Nature Network (funded by NERC, ESRC, BBSRC, AHRC and Defra). Individual contributors to that review provided their input voluntarily. 
This article is based on their work. The authors thank the reviewer and editor for their valuable comments. 


\begin{abstract}
There is increasing interest in the use of economic valuation of ecosystem goods and services for a wide variety of purposes. These include relatively familiar uses in project appraisal and more novel applications in advocacy, performance tracking and accounting in public and private settings. Decision makers who use valuation information need to understand the background, strengths and weaknesses of these approaches. The methods have a strong foundation in economic theory and offer a rapidly growing evidence base, improving ability to evaluate a broad range of ecosystem goods and services. Nevertheless, there are theoretical and practical limitations that need to be understood and kept in mind when interpreting results. In this paper, we briefly review the economic valuation methods and situate them in their historical and theoretical contexts. We assess the main critiques, attempts at resolving them, and implications for the usefulness of the methods in different contexts. We examine the main barriers and opportunities for wider uses of valuation evidence, and draw conclusions on the appropriate role of valuation in future, as a tool for aiding reflection and deliberation processes.
\end{abstract}

Keywords: economic valuation; criticisms of economic valuation; stated preference; revealed preference; externalities; ecosystem services; policy appraisal; decision support. 


\section{Introduction}

Market systems and economic appraisal methods offer powerful tools for supporting decisions about the allocation of scarce resources. However there are many important aspects of human activity that are not fully reflected in market prices, including our impacts on the natural world and our dependence on the many valuable goods and services provided by ecosystems. With the aim of improving decision-making processes, there is increasing interest from research providers, policy makers and private sector decision makers in economic valuation of ecosystem goods and services (hereafter referred to as economic valuation).

A short paper (Ozdemiroglu and Hails, 2016) was drafted using contributions from 120 research providers and users to answer frequently asked questions about economic valuation. At the same time, a longer review of the concepts and practice was prepared by a subset of those contributors. This article is based on that longer review, and is written for a general audience with basic knowledge about economic valuation. It presents a summary of the conceptual background and history of economic valuation, an assessment of current methods, a discussion of practical applications, a critique of key uncertainties and assumptions, and concludes with consideration of barriers and opportunities for future developments and uses.

\section{Conceptual background to economic valuation and its history}

Economic valuation has a long history (Gómez-Baggethun et al., 2010) with roots in Pre-classical economics (1650-1750), when 'land' was central to economic theory as a primary source of wealth (Petty, 1664). During Classical economics (1750-1875), the importance of nature's services was widely recognised (Malthus, 1853, Marx, 1887), although ecology did not exist as a discipline until the late 1800s, and the 'ecosystem' concept was not introduced until Tansley (1935). Following the industrial revolution, the significance of the environment waned in Neoclassical economic theory (1875 onwards) with attention focused on human-made capital and labour.

The $20^{\text {th }}$ century saw renewed interest in the environmental impacts of economic activity, and in the dependence of the economy, and human welfare, on healthy natural 
systems. Pigou (1920) introduced welfare economics and the concept of externality, leading to the development of environmental economics and the foundations of economic valuation (notably Hicks, 1939, 1943; Hotelling, 1947; see Pearce, 2002).

The first important applications came in the 1960s, with valuation of environmental resources underpinning new legislation in the USA, in particular the Clean Air (1963) and Clean Waters (1972) Acts. Early examples of the methods included Clawson (1959), Davis (1963), Clawson and Knetsch (1966) and Ridker (1967). The development and application of economic valuation continued through the 1970s and 1980s, for example with progression from zonal to individual travel cost models (Brown and Nawas, 1973, Gum and Martin 1974), and the development of Contingent Valuation (e.g. Randall et al., 1974) and its subsequent adoption in the USA as a means of estimating damages to environmental resources (Cummings et al., 1986, Mitchell and Carson, 1989). In the UK, 'Blueprint for a Green Economy' (Pearce et al., 1989) and the following White Paper ('This Common Inheritance': HMSO, 1990) sought formal inclusion of environmental impacts in policy appraisal.

The 1990s brought continued refinement of valuation methods, for example through the introduction of discrete choice experiments and random utility models in stated and revealed preference studies (Adamowicz et al., 1994, Boxall et al., 1996, Hanley et al., 1998). Nordhaus $(1992,1993)$ pioneered integrated assessment models linking the global economy, energy use and climate change, estimating the value of damages caused by greenhouse gases.

Alongside the development of environmental economics, dissenting voices (Boulding, 1966, Meadows et al, 1972, Daly, 1973) led to the emergence of ecological economics, treating the economy as a subsystem of the global ecosystem, with a greater focus on systemic approaches to the preservation of natural capital, justice and equity, and issues of irreversibility and uncertainty (van den Bergh, 2001; Faber, 2008). "Doughnut economics" (Raworth, 2018) crystalizes many of these ideas, for example rejecting the focus on GDP growth and promoting the circular economy and reducing inequality as key objectives.

Ecological and environmental economics remain in some ways separate approaches (Illge and Schwarze, 2006), though with considerable overlap in terms of both approaches and practitioners. For valuation, the main differences have been in how values are combined and used to support decision making. However, recent work on valuation methods in ecological 
economics (Irvine et al., 2016; Kenter et al., 2015) has sought to distance itself from neoclassical approaches principally by suggesting that many environmental values are social and shared, and are thus formed in response to specific situations, as opposed to being associated with the 'utility functions' of independent individuals.

Costanza et al. (1997) combined environmental economics with an ecosystem services framework to 'value' the world's ecosystem services at US\$33 trillion per year. The Costanza study was theoretically flawed ${ }^{1}$ in seeking a total value for the ecosystems on which all life depends (Fisher et al. (2009) described it as "a serious underestimate of infinity") but successfully raised awareness of the ecosystem services paradigm and non-market valuation, shifting them into mainstream debate.

Ongoing loss of biodiversity and ecosystems was highlighted in studies such as the Millennium Ecosystem Assessment (MA, 2005) and various National Ecosystem Assessments (including those in the UK: UKNEA 2011 and 2014), with a direct link being made to economic losses and decline in human wellbeing. The Economics of Ecosystems and Biodiversity (TEEB $)^{2}$ has played a global role in "making nature's values visible". The European Commission supported TEEB via several projects, including the Cost of Policy Inaction study (Braat and ten Brink, 2008) which gave a conservative and partial estimate that the global cost of additional biodiversity loss after 2000 would reach $7 \%$ of world GDP by 2050.

The numbers of papers and projects using ecosystem services have risen dramatically and the concept is now ingrained in policy across the world. The European Environment Agency (EEA) has led work to develop the Common International Classification of Ecosystem Services (CICES) ${ }^{3}$ and the US Environment Protection Agency (EPA) has

\footnotetext{
${ }^{1}$ Despite the flaws, the study remains useful, both as an awareness-raising exercise, and through setting a baseline for comparisons using consistent methods: a follow up (Costanza et al, 2014) updated the unit values and took account of land use/land cover change from 1997-2011, showing a higher total value (due to revaluation) but a substantial loss due to land use change. See also the review by Costanza et al (2017).

${ }^{2}$ http://www.teebweb.org/

${ }^{3}$ http://cices.eu/
} 
developed the Final Ecosystem Goods and Services Classification System (FEGS-CS) ${ }^{4}$. The Intergovernmental Science-Policy Platform on Biodiversity and Ecosystem Services (IPBES) was set up in 2012 to assess the state of biodiversity and of the ecosystem services it provides to society, in response to requests from decision makers ${ }^{5}$.

Alongside these developments, a growing number of original economic valuation studies, meta-analyses of economic valuation studies (e.g. Brouwer et al., 1999; Brander et al., 2011) and economic valuation databases ${ }^{6}$ has consolidated the evidence base and facilitated the transfer of economic value estimates to new contexts (such transfer being considered contentious by some: see e.g. Ravenscroft, 2019). The mainstreaming of economic valuation is demonstrated by the development under the environmental management systems series International Standards Organisation (ISO) 14000 (the bestselling standard in the world) of ISO 14007 "Environmental management: Determining environmental costs and benefits - Guidance"7 and ISO $14008^{8}$ "Monetary valuation of environmental impacts and related environmental aspects". Despite this progress, economic valuation of biodiversity remains notoriously difficult: the risks of unintended interpretations and undervaluation make it particularly important that both qualitative and quantitative narrative is presented as well as what is possible to express in monetary terms.

\subsection{The concept of value in neoclassical economics}

In neoclassical economics, "value" is grounded in utilitarianism, an ethical theory traced back to Hume (1751) and Bentham (1789) and with roots in the Greek Hedonist philosophers. Utilitarianism holds that the best moral action is the one that maximizes utility. Utility in turn can be variously defined, but is generally related to the well-being of sentient beings. In neoclassical economics, only anthropocentric values (including passive and non-

\footnotetext{
${ }^{4}$ https://www.epa.gov/eco-research/final-ecosystem-goods-and-services-classification-system-fegs-cs

${ }^{5}$ www.ipbes.net/about

${ }^{6}$ See in particular the Environmental Valuation Reference Inventory (EVRI) (www.evri.ca), the TEEB valuation database (http://es-partnership.org/services/data-knowledge-sharing/ecosystem-service-valuation-database/; de Groot et al., 2012), the Envalue database (http://marineecosystemservices.org/explore) and the Marine Ecosystem Services Partnership's (MESP) Valuation Library (http://marineecosystemservices.org/explore).

${ }^{7}$ https://committee.iso.org/sites/tc207sc1/home/projects/ongoing/iso-14007.html

${ }^{8}$ https://committee.iso.org/sites/tc207sc1/home/projects/ongoing/iso-14008.html
} 
use values) are taken into account. Non-anthropocentric and intrinsic values, for which we have no assessment methods, are excluded, though they may be acknowledged as boundaries on economic valuation with respect to our obligations to other beings and objects.

Human utility is assessed using the framework of expected utility theory (von Neumann and Morgenstern, 1944) following the assumption that individuals act as 'rational utility maximisers' whose decisions and behaviour stem from preferences accurately reflecting their utilities. Related values are reflected through individual choices under a budget constraint, expressed as 'willingness to pay' (WTP) to secure a gain or avoid a loss, or 'willingness to accept' (WTA) compensation to forgo a gain or tolerate a loss.

Although based on individuals' preferences, the Total Economic Value (TEV) framework (Figure 1) is not limited to 'selfish' values. In addition to values for their own direct and indirect uses of goods and services, people often have altruistic preferences for others, for future generations (bequest value) and for aspects of the natural world in their own right (existence value). These "non-use values" are expressed, for example, via charitable donations. The framework was recently extended by Pascual et al. (2015) to include 'insurance' values, related to uncertainty about outcomes and preferences, and associated willingness to pay to mitigate risks, to adapt to risks, or to preserve options to use resources if circumstances change.

[Figure 1 about here]

\subsection{Values in markets}

The use of money and markets allows huge efficiency gains compared with systems of barter or directed activities. Individuals express their preferences via market demands for goods and services, and their supply of labour and assets, while firms express values through demand for resources and labour, and supply of goods and services. A well-functioning market enables mutually beneficial trades and the market 'clears' at a price at which all people willing to trade at that price can do so, maximising the economic surplus produced. 
'General equilibrium' (Walras, 1877) implies simultaneous clearing of all markets, such that the prices in each market represent the opportunity $\operatorname{costs}^{9}$ of the resources used to produce the good or service. Through adjustments of prices in response to supply and demand, a full set of perfectly functioning markets would achieve efficient allocation of scarce resources, maximising economic surplus, and achieving a 'Pareto optimum' in which it is not possible to make any person better off without making someone worse off (Pareto, 1906). There are many possible Pareto optimal equilibria: which one 'perfect' markets would in theory reach depends on the initial distribution of 'endowments' (property rights), and the social choice among them is a normative matter of 'fairness'.

At the societal level, taxation and redistribution policies can be used to improve fairness (see e.g. Hochman and Rodgers, 1969, Stiglitz, 1987). Individual economic appraisals generally apply the Kaldor-Hicks rule (Hicks, 1939, Kaldor, 1939) that a change is beneficial if the 'winners' could fully compensate the 'losers' and still be better off. But with no actual compensation, in practice appraisals allow gains to some people to offset losses to others.

In reality, while market prices guide individual choices, various 'market failures' (see Bator, 1958) mean they do not always reflect social values, resulting in (Pareto-)inefficient outcomes. Some important failures include those presented in Table 1.

Table 1: Market failures: description, example and possible solutions

\begin{tabular}{|l|l|l|l|}
\hline Failure & Description & Example & Possible solutions \\
\hline $\begin{array}{l}\text { Distortionary } \\
\text { taxes }\end{array}$ & $\begin{array}{l}\text { Taxes/subsidies influence } \\
\text { incentives }\end{array}$ & $\begin{array}{l}\text { Fossil fuel } \\
\text { subsidies }\end{array}$ & Remove \\
\hline $\begin{array}{l}\text { Externality / } \\
\text { missing markets }\end{array}$ & $\begin{array}{l}\text { Impacts of activities not } \\
\text { fully considered by actors }\end{array}$ & $\begin{array}{l}\text { Pollution } \\
\text { Open access }\end{array}$ & $\begin{array}{l}\text { Taxes, quotas, } \\
\text { standards; } \\
\text { Clarify property rights }\end{array}$ \\
\hline $\begin{array}{l}\text { Imperfect } \\
\text { competition }\end{array}$ & $\begin{array}{l}\text { Market power allows price } \\
\text { manipulation }\end{array}$ & $\begin{array}{l}\text { OPEC raising } \\
\text { oil prices }\end{array}$ & Antitrust regulations \\
\hline
\end{tabular}

\footnotetext{
${ }^{9}$ Opportunity cost is the value in 'next best use', e.g. switching the resource from production of good A to good
} B. 


\begin{tabular}{|l|l|l|l|}
\hline $\begin{array}{l}\text { Imperfect } \\
\text { information }\end{array}$ & $\begin{array}{l}\text { Choices do not reflect } \\
\text { values }\end{array}$ & $\begin{array}{l}\text { Asbestos, } \\
\text { DDT, } \\
\text { ecosystem } \\
\text { tipping points }\end{array}$ & $\begin{array}{l}\text { Research and education, } \\
\text { precautionary principle } \\
\text { Labelling, regulations }\end{array}$ \\
\hline
\end{tabular}

For ecosystem goods and services, the main market failure is often externality, because many ecosystem goods and services that benefit people are not traded in markets. This drives a wedge between market outcomes and socially desirable outcomes. Policies may address such failures in various ways, including changing prices (taxes, subsidies), controlling quantities (quotas, permits) or restricting activities and technologies and activities (regulations, bans). To support policies, and for appraisal (notably cost benefit analysis), one useful option is to estimate economic values for non-market goods and services in monetary units. Economic valuation methods seek to extend the scope of economic analysis to consider all the consequences of decisions that enter utility and production functions, not only those that are traded in markets, allowing comparisons of relative values across impacts, people, time, and decisions.

\section{Economic valuation methods}

Values for goods and services traded in markets are generally estimated through observed prices, or sometimes econometric estimation of demand curves for non-marginal changes. Where there is market failure, prices can be adjusted or estimated to derive 'shadow prices' that reflect social benefits and costs.

Where a non-market good is closely related to a market one, proxy values may be identified. For example, home-grown or gathered food can be valued using market prices for equivalent produce. Sometimes, statistical analysis can derive 'production functions' relating changes in some ecosystem function to production of a good or service that can be valued (Barbier, 2007). For example, production functions relating air pollution to crop yields (market values) and human health (non-market values) estimate air pollution damages in mainland China at 5.7-6.6\% of GDP (Miao et al, 2017). The primary difficulty is the availability of scientific knowledge and/or data for estimating the production function. 
Where market values cannot be used or adjusted, there are two main approaches to valuation: revealed preference and stated preference.

\subsection{Revealed preference}

Revealed preference methods analyse relationships between demand for some market goods and preferences for related non-market goods/services. These methods only work if changes in provision of the non-market good have an observable impact on the demand for a market good. Examples include property and labour markets (hedonic methods), demand for recreation (travel cost), and demand for products that compensate for losses in environmental services (averting behaviour).

Averting behaviour approaches involve estimating household 'production functions' that allow calculation of values for risks and disamenities via the expenditures households incur to avoid them - for example to avoid exposure to pollution (Bartik, 1988) or risks associated with groundwater contamination (Abdalla et al., 1992). Problems include for example joint impacts (e.g. double glazing will impact both noise and thermal comfort), 'lumpiness' in investments and transactions costs (see Courant and Porter, 1981) and imperfect information about risks, effectiveness of measures, and the endogeneity of risk perceptions (Lloyd-Smith et al., 2018).

Hedonic pricing has a similar theoretical background (Rosen, 1974). Common applications seek to value environmental quality aspects of housing via statistical analysis of property markets (see Boyle and Kiel, 2001). Sale/rental values of properties are modelled as a function of property 'attributes' including environmental quality (such as noise nuisance (Day et al., 2007), air pollution (Smith and Huang, 1993), or proximity to desirable features, such as an urban green space (Czembrowski and Kronenberg, 2016) or undesirable features such as landfill sites (Hite et al., 2001)). The method only accounts for use values associated with occupation of the property and does not cover values to non-residents. The method assumes markets are perfectly functioning, though people may have poor knowledge regarding both the levels and the impacts of some attributes (e.g. air pollution), and housing markets generally have high transactions costs (taxes and moving costs) and may therefore respond slowly to changed conditions (Freeman, 1981). Hedonic wage methods use a similar 
approach to value risks to health/life, via the wage premium for dangerous jobs (Liu et al., 1997).

Travel cost methods use costs incurred travelling to and at a site, including the cost of time, as a proxy for the price of recreation. This is combined with information about visit rates to derive an estimate of the value of recreation at the site. The main methodological concerns include the valuation of travel time (Bockstael et al., 1987), the analysis of multi-site and multi-purpose trips, and accounting for substitute sites and activities (Ward and Beal 2000). Early applications focused on single sites, but modern methods use Random Utility models (Phaneuf and Smith, 2005) focusing on individuals' choices from a set of alternative sites, modelled as a function of site characteristics and individual factors including income and travel costs.

\subsection{Stated preference}

Stated preference methods are based on surveys which create hypothetical markets for respondents to express their preferences: ${ }^{10}$

- Contingent valuation (CV) asks directly how much respondents are willing to pay to secure the change presented, or willing to accept compensation to avoid it ${ }^{11}$, via openended questions or different forms of bidding formats.

- Discrete choice experiments (DCE) are based on respondents' choices for their preferred scenario among alternatives. Scenarios are described by different combinations of the goods and services in terms of their environmental as well as cost attributes, each taking different levels in each scenario. Information on the values that people assign to improvements in the different goods and services are indirectly inferred from the trade-offs that people are willing to make when choosing their preferred alternatives.

\footnotetext{
${ }^{10}$ Recent reviews of the CV and DCE include Venkatachalam (2004), Hoyos (2010), Kling et al. (2012) and Johnston et al. (2017).

${ }^{11}$ Rare in practice since the framing of compensation for accepting damages tends to trigger protest responses.
} 
Both CV and DCE formats enable estimation of WTP (or WTA) for the good or service as a whole; DCE also allows for the calculation of implicit prices of specific attributes. One advantage of stated preference (over revealed preference) methods is that they can elicit preferences for scenarios that are yet to occur, therefore providing ex-ante information on expected WTP to inform the design of future policies. Another is the ability to capture nonuse values as well as use values.

Responses in stated preference surveys may show high sensitivity to factors that should not matter (according to economic theory) and/or insensitivity to factors that should. Examples of the former are starting-point/anchoring/range biases (Chien et al., 2005, Whynes et al., 2004), where the amounts proposed as WTP options in the survey influence the responses, and order effects, where the order in which components of the good are valued affects overall stated value (Day et al., 2012, Powe and Bateman, 2003). Examples of the latter are the failure of the valuation to vary with the scope or quantity of the good (e.g. Powe and Bateman, 2004, Veisten et al., 2004). Critics argue that hypothetical questions generate hypothetical, invalid responses (Hausman, 2012) and WTP from surveys often exceeds WTP with real payments (Little and Berrens, 2004, Fifer et al., 2014). Respondents may have strategic motives to misreport WTP, to make a 'protest' bid (false zero or inflated WTP) or to refuse to express preference, not because they are indifferent, but because they reject the valuation scenario, the implied property right, or the valuation approach (Jorgensen et al., 1999, Meyerhoff and Liebe, 2010). Substantial research has helped develop strategies to limit these potential biases through careful study design and testing (Carson and Groves, 2007, Meyerhoff and Liebe, 2006, Cummings and Taylor, 1999, Atkinson et al., 2012).

Stated preference methods can assess the WTP for an environmental improvement or the willingness to accept (WTA) compensation for deterioration. WTA can be greater than WTP for an equivalent change due to income effects, but in empirical studies this discrepancy tends to be greater than theory predicts (Brown and Gregory, 1999, Horowitz and McConnell, 2002). Behavioural explanations such as an endowment effect or loss aversion (Tversky and Kahneman, 1991) and ambiguity of the transaction and expected regret (Loomes and Sugden, 1982) have been proposed. None of these concepts have sufficiently explained the differences observed in empirical studies. The difficulties of deriving unbiased estimates of WTA mean that WTP is almost always used, though this underestimates WTA and remains controversial. 


\section{Valuation in practice}

There are many applications for valuation evidence that may call for different methods, coverage, accuracy and research expenditure, and may evoke different ethical and practical objections (see e.g. Beaumont et al., 2018, Gómez-Baggethun and Barton, 2013, Laurans et al., 2013). The article by Curnow in this special issue (2019) is a summary of the current use of economic evidence in environmental policy by the UK government. In general, applications include:

- Demonstrating economic value, advocacy

- Project/policy appraisal, impact assessment

- Prioritising investments

- Demonstrating 'Value for Money', seeking funding

- Informing planning/location decisions

- Monitoring/review of decisions

- Environmental accounting

- Informing pricing decisions: fees, payments, compensation

Valuation is sometimes attempted for whole systems (e.g. WTP to protect a specific natural area). In general however an attempt is first made to quantify environmental impacts as changes in physical values (such as tonnes of carbon storage, crop production, flood risks) and then to ascribe an economic value for each physical unit. There is also an important distinction between stocks of 'assets' (e.g. total carbon stored) and flows of goods and services (e.g. carbon sequestered per year) (Ozdemiroglu, 2019).

For most practical purposes, value transfer is used to draw values from existing studies to use as proxies in analysis. This is cheaper and quicker than conducting original studies. The simplest type, unit transfer, directly applies an estimate of value made for one site or location to another. A more sophisticated approach uses a value function describing the relationship between value and key environmental and population factors influencing it. Meta-analysis can be used to estimate a composite value function based on several studies. Value estimates based on careful meta-analysis of several good-quality studies may produce narrower confidence intervals than a single study, provided the meta-analysis take sufficient account of variability in socioeconomic and biophysical factors (Schmidt et al., 2016). 
The most familiar and widespread application is project appraisal using cost-benefit analysis (CBA) (see Boardman et al., 2017, OECD, 2018). CBA compares all the benefits and costs of project/policy options that can be valued in monetary terms. These are discounted to convert future values to present-day equivalents, then aggregated to give expected $^{12}$ net present value. CBA can compare options for a specific decision, and rank/prioritise spending options in terms of their net present value, benefit: cost ratio, or internal rate of return. Extensive official guidance for appraisal exists in many jurisdictions, including the UK (HMT, 2018), the EU (EC, 2015), US (EPA, 2010) and so on. Guidance for value transfer is also available (e.g. eftec, 2010 as formal guidance from UK Defra).

Discounting can be justified through social time-preference (people value benefits now more than benefits later) and/or returns to investment (projects should bring greater social return than alternative uses for funds) (see HMT, 2018). The choice of discount rate is however hard to justify objectively (Arrow et al., 2012) but has great influence over results (Weitzman, 2007). National governments and international institutions typically have a standard rate to ensure consistent discounting across all public sector appraisals (European Commission, 2015; HMT, 2018). Some argue that discounting is inappropriate for long-term, significant environmental changes (Stern, Peters et al., 2006, Saez and Requena, 2007, Stern and Taylor, 2007, Faccioli, Hanley et al., 2016) because the standard discount rates of a few percent result in huge discounting of long-term impacts - which for climate policy, for example, could justify a "wait and see" approach. Some advocate declining or hyperbolic discount rates (Kirby, 1997), others a low constant rate. Heal and Millner (2014) argue that there are no objectively correct discount rates, just different ethical positions that need to be weighted: climate policy analysis "becomes an exercise in social choice" that requires aggregating "the diverse preferences of individuals into a representative discount rate". At any rate, CBA should consider the impact of the discount rate on the analysis, including sensitivity analysis using different discount rates and explicit discussion of impacts in different time periods (HMT, 2018) $)^{13}$

\footnotetext{
12 Assuming calculable risks about future costs and benefits; other statistical treatments are also possible.

${ }^{13}$ The 2018 version of the HM Treasury Green Book introduces a 'health discount rate' starting at $1.5 \%$ and declining over time (compared to social discount rate starting at 3.5\%). The difference is due to the exclusion of
} 
Although valuation is primarily used in public sector settings, there is increasing uptake in the private sector, for example for determining customer priorities, assessing impacts and dependencies on natural systems, communication and performance tracking including natural capital and ecosystem accounting. Initiatives include, for example, The Natural Capital Project ${ }^{14}$, the World Business Council on Sustainable Development ${ }^{15}$, and the Natural Capital Coalition ${ }^{16}$ at the international level, and water company business planning in the UK. Wales (2014), Bowe and van der Horst (2015), Dickie et al., (this issue) and Koshy et al., (this issue) give examples of how and why private organisations use economic valuation for natural capital accounting.

\section{Critiques of valuation}

Using market values to account for goods and services traded in markets, including ecosystem goods (food, timber etc.), is relatively uncontroversial. But use of economic values for nonmarketed services such as clean air provision or biodiversity protection has been criticised on many fronts (Table 2).

Table 2: Valuation assumptions, problems and resolutions

\begin{tabular}{|l|l|l|l|}
\hline Assumption & Problem? & Generalisation & Resolution? \\
\hline Individuals' & Sometimes false (e.g. & Democratic societies & Recognise TEV \\
preferences strongly & drug addiction), often & allow wide freedom & focuses on \\
correlated with & dubious (e.g. myopic & of choice under rules & individual \\
welfare & preferences and & to curb excesses, & preference, \\
& regret: Hoch and & encourage saving etc. & $\begin{array}{l}\text { consider other } \\
\text { moral decision } \\
\end{array}$ \\
& Loewenstein, 1991). & & \begin{tabular}{l} 
rules in \\
\hline
\end{tabular} \\
\hline
\end{tabular}

'wealth effect', or real per capita consumption growth element of the discount rate when discounting health effects (HMT, 2018, p 103).

${ }^{14}$ www.naturalcapitalproject.stanford.edu

15 www.wbcsd.org

${ }^{16}$ www.naturalcapitalcoalition.org 


\begin{tabular}{|c|c|c|c|}
\hline & & & $\begin{array}{l}\text { deliberative } \\
\text { processes. }\end{array}$ \\
\hline $\begin{array}{l}\text { Individuals have } \\
\text { information and } \\
\text { ability to have stable, } \\
\text { well-formed } \\
\text { preferences they } \\
\text { express through } \\
\text { decisions }\end{array}$ & $\begin{array}{l}\text { People have } \\
\text { "bounded rationality" } \\
\text { (March and Simon, } \\
\text { 1958), construct } \\
\text { preferences (Slovic, } \\
\text { 1995), especially for } \\
\text { hypothetical } \\
\text { decisions, unfamiliar } \\
\text { goods/services }\end{array}$ & $\begin{array}{l}\text { Affects other } \\
\text { methods. Market } \\
\text { institutions consistent } \\
\text { with assumptions, } \\
\text { with limits } \\
\text { (advertising, trade } \\
\text { descriptions...). }\end{array}$ & $\begin{array}{l}\text { Cognitive limits } \\
\text { may support } \\
\text { procedural } \\
\text { rationality (Laville, } \\
\text { 2000). Reduce } \\
\text { bias via } \\
\text { information, } \\
\text { thinking time, } \\
\text { deliberation. }\end{array}$ \\
\hline $\begin{array}{l}\text { Interpersonal } \\
\text { comparability of } \\
\text { utility }\end{array}$ & $\begin{array}{l}\text { Identical indicators of } \\
\text { benefit to different } \\
\text { individuals may } \\
\text { represent different } \\
\text { levels of human } \\
\text { welfare (d'Aspremont } \\
\text { and Gevers, 2002). }\end{array}$ & $\begin{array}{l}\text { Affects any system } \\
\text { (including voting } \\
\text { systems), not limited } \\
\text { to monetary units. }\end{array}$ & $\begin{array}{l}\text { Practical option is } \\
\text { to act 'as if' } \\
\text { comparisons } \\
\text { reliable, and use } \\
\text { income weighting. }\end{array}$ \\
\hline $\begin{array}{l}\text { Values constrained } \\
\text { by ability to pay }\end{array}$ & $\begin{array}{l}\text { Raw value estimates } \\
\text { assume that income } \\
\text { distributions are } \\
\text { desirable/fair }\end{array}$ & $\begin{array}{l}\text { Tax/benefit policies } \\
\text { redistribute incomes } \\
\text { so actual distributions } \\
\text { partly reflect } \\
\text { democratic processes. }\end{array}$ & $\begin{array}{l}\text { Income weighting } \\
\text { to adjust values in } \\
\text { transfer/appraisal. }\end{array}$ \\
\hline $\begin{array}{l}\text { Smooth, continuous } \\
\text { value functions }\end{array}$ & $\begin{array}{l}\text { Non-linearities, } \\
\text { threshold effects and } \\
\text { areas of highly } \\
\text { inelastic demand / } \\
\text { rapidly changing } \\
\text { values }\end{array}$ & $\begin{array}{l}\text { Small-scale, marginal } \\
\text { assessments less } \\
\text { likely to suffer than } \\
\text { large-scale, major } \\
\text { changes. }\end{array}$ & $\begin{array}{l}\text { Valuation less } \\
\text { useful for critical } \\
\text { natural capital or } \\
\text { potentially } \\
\text { catastrophic } \\
\text { changes. }\end{array}$ \\
\hline $\begin{array}{l}\text { Data gaps in } \\
\text { scientific }\end{array}$ & $\begin{array}{l}\text { No valuation or } \\
\text { appraisal can be }\end{array}$ & $\begin{array}{l}\text { Applies to all } \\
\text { methods: use range of } \\
\text { values, sensitivity }\end{array}$ & $\begin{array}{l}\text { Valuation/appraisal } \\
\text { are aids to }\end{array}$ \\
\hline
\end{tabular}




\begin{tabular}{|l|l|l|l|}
\hline $\begin{array}{l}\text { understanding and } \\
\text { valuation evidence }\end{array}$ & $\begin{array}{l}\text { complete and } \\
\text { accurate }\end{array}$ & $\begin{array}{l}\text { analysis, clear } \\
\text { statements of gaps. }\end{array}$ & $\begin{array}{l}\text { deliberation, not } \\
\text { "the answer". }\end{array}$ \\
\hline $\begin{array}{l}\text { Optimism bias: } \\
\text { tendency to } \\
\text { underestimate future } \\
\text { costs and } \\
\text { overestimate benefits }\end{array}$ & $\begin{array}{l}\text { CBA likely to be } \\
\text { biased (see Mackie } \\
\text { and Preston, 1998). }\end{array}$ & $\begin{array}{l}\text { More about physical } \\
\text { outcomes and timings } \\
\text { than valuation } \\
\text { methods. }\end{array}$ & $\begin{array}{l}\text { Recognise and } \\
\text { adjust for optimism } \\
\text { (or 'pessimism') } \\
\text { bias. }\end{array}$ \\
\hline
\end{tabular}

Aggregating individual preferences to produce a well-characterised social preference ordering leads to tractable social value functions, with obvious practical advantages for decision support. Hence, the neoclassical approach dominates welfare economics both in theory and in practice. However, expected utility theory does not always provide a reliable guide to individual human behaviour, and the derived social orderings may not accord with actual social preferences.

Evidence from economics and psychology has raised questions about the rationality of actual decisions (Thaler and Sunstein, 2008; Thaler, 2015), identifying situations in which expected utility theory fails to explain people's behaviour. Framing effects and preference reversals arise in quite simple settings and people consistently put more weight on potential losses than on gains (Allais, 1953, Lichtenstein and Slovic, 1971, Kahneman and Tversky, 1979). For complex decisions, deviations from the expected utility theory are widespread (see e.g. Barberis and Thaler, 2003). Valuation methods presuppose that choice-makers are fully aware of how alternative choices would influence their welfare. However, information and calculation requirements for 'rational choice' may be extensive, especially in environmental contexts where links from environmental change to human welfare are poorly understood, even by experts. In some situations, individual preferences may be vague or simply 'wrong' in respect of welfare impacts. For such 'wicked' problems, economic valuation estimates may be skewed, and cost-benefit analyses may not be a good guide to the relative desirability of outcomes.

This might not matter if on average economic systems operate "as if" economic agents were rational utility maximizers (Friedman, 1953). However, models built assuming such agents underplay or ignore human interactions, cognitive limitations, and biases and do not reliably predict the evolution of economies (Colander et al., 2009). Furthermore, even with 
the "as if" assumption, treating aggregate TEV as an index of social welfare involves two further assumptions: inter-personal comparability of utility (to aggregate preferences) and that underlying income distributions are socially acceptable.

Despite the recognised problems, these assumptions may be an acceptable approximation. Through market exchanges, our economic structures use these values, and tax/welfare policies redistribute incomes following democratic processes. However, extending valuation and market framings to areas where market mechanisms and property rights have not been defined is ethically contentious and may have unintended consequences (Vatn, 2000; Kosoy and Corbera, 2010, Sullivan, 2013) in terms of fairness and behaviour.

Environmental taxes tend to represent a greater proportion of income for poorer groups. However the revenues raised could compensate for this, for example via reductions in other distortionary, regressive taxes (e.g. VAT, labour taxes). It can also appear more 'efficient' to cluster environmental 'bads' where people are poorer, because their WTP (constrained by income) is lower. Valuation and appraisal can be adjusted via income weighting (rare) and/or use of average (mean or median) WTP values for whole populations (common), but full accounting for distributional impacts is rare and more attention might be given to this area.

'Crowding out' of non-market motives and values does occur where policy instruments introduce economic incentives and as a result modify people's motivational structures (Rode et al., 2015). But the use of monetary valuation in appraisal is a matter of framing benefits in a certain way, rather than any change in incentive structures, and so may be less likely to lead to crowding out of other arguments and motivations in deliberation (Tinch et al., 2018). Furthermore, individual preferences and WTP can reflect otherregarding values and moral norms, notably through non-use values. Using these values for social choice assumes that "the ecological, social and cultural dimensions of value can be both compared and compensated fully and justly" (Kenter et al., 2015) and that contentious issues regarding inter- and intra-generational equity are adequately resolved via assumptions about discounting and treatment of income distribution. If individuals have context-specific values/preferences - values used in market exchange settings may be quite different from values used in group deliberation or public choice - the methods cannot give a single 
consistent ranking of policy alternatives (Kenter et al., 2015; Parks and Gowdy, 2013). However, this applies to all approaches, not just valuation ${ }^{17}$.

Valuation assumes full knowledge about the ways changes in environmental goods and services influence utility functions. But these linkages are often complex and poorly understood (Cardinale et al., 2012). There are many sources of complexity, variability, and uncertainty, both in bio-physical systems and in human preferences and technologies. resulting in accumulating uncertainty throughout stages of valuation. There may be delays, threshold effects, and different impacts at various spatial and temporal scales (Muradian, 2001, Kremen, 2005, Groffman et al., 2006). Individuals are not risk-neutral regarding environmental outcomes, so recognising, communicating and treating uncertainty can lead to significantly different results in valuation studies (Faccioli et al., 2018). The common practice of focusing on expected values can also be also problematic, especially where 'fat tails' of low-probability but highly damaging outcomes should motivate precautionary policies (Taleb, 2014, Weitzman, 2009).

The value of a good or service can vary with its quantity and quality and hence most values represent a marginal value relating to a specific context. For many environmental services, demand can be quite 'elastic' at high levels of provision, but inelastic for lower levels, and effectively 'infinite' for essential services or 'critical natural capital' (see Chiesura and De Groot, 2003). This puts limits on the applicability of valuation, with valuation relatively unproblematic under elastic demand, less reliable under inelastic demand, and not appropriate for critical capital.

Coverage in any case is limited to the estimated part of total economic value, and in practice this rarely covers all sources of value, due to incompleteness of the evidence base linking environmental features to valuable services. Critical elements of the natural environment may be overlooked in decision processes if they are not recognised as important. For example, we often underestimate the value of biodiversity and ecosystems by failing to account for the ways they support provision of food and water, and provide natural insurance

\footnotetext{
${ }^{17}$ Arrow's impossibility theorem (Arrow, 1950) proves that for any method of aggregating individual preferences, individual preference patterns can exist such that it is impossible to derive a social ranking that meets minimal conditions of consistency, non-dictatorship, universality, monotonicity, and independence.
} 
to adapt to future conditions and shocks. Again, this is a problem for decision support generally, not just valuation. Primary research can help, but it is not always practical to wait until scientific uncertainty is resolved. In most cases, it is necessary to take decisions under uncertainty, making best use of the information available. Appraisal results should be tested for sensitivity to assumptions used, and any risks, uncertainties, missing data, and other caveats must be clearly and fully reported.

Economists recognize all these issues, but use TEV and CBA for practical reasons: many of the objections can be adjusted for to some extent, and no approach is perfect. A critical question is whether or not the evidence is actually useful, and this will depend on the deliberation and decision-making processes and the individuals involved. Views differ widely. Flyvbjerg (2009) argues that errors in forecasting are so substantial that CBA will almost always be "strongly misleading," summarising this as "Garbage in, garbage out". Conversely, Asplund and Eliasson (2016) conclude that, despite pervasive uncertainties, CBA "is able to fairly consistently separate the wheat from the chaff and hence contribute to substantially improved infrastructure decisions." eftec (2010b) reviewed the CBA of conservation projects, finding that, while there are few clear examples of "near-perfect" CBA studies, there are several examples that are "good enough" to provide a useful aid to decision making within a given context.

Other techniques exist that elicit different expressions of social preferences, including deliberative monetary valuation, ranking, participatory multi-criteria analysis, citizen juries, in-depth discussion groups, participatory modelling and mapping, and so on. These alternative decision support and/or valuation methods do not resolve all the concerns identified for valuation and CBA, and may introduce new ones, but can be useful in allowing different perspectives on social choice. Alternative decision rules may for example prioritise precaution and robustness over maximisation of expected values. In many cases these methods can be complementary to valuation and CBA, with evidence from several methods being incorporated within a wider deliberative process.

It is widely recognised by economists (see e.g. TEEB, 2010, Diaz et al., 2018) that monetary valuation and cost benefit analysis only provide one form of evidence to support decision making, that should be used as a complement to ethical and scientific analyses, and consideration of various opinions relating to environmental exploitation and conservation. 
Monetary valuation, and decision support using it, should never be treated as the 'right' answer, nor as an alternative to deliberation. Rather, valuation is a support to thinking about difficult decisions, and a way of summarising certain forms of information in a convenient and tractable fashion. Of course there remains a risk of results being misused - for example being "cherry-picked" to support pre-determined conclusions - but this problem is hardly unique to valuation.

\section{Barriers and prospects for economic valuation}

Use of economic valuation to support decisions remains piecemeal. Some argue that there are few clear examples of economic valuation having an influence (Laurans et al., 2013) and that ecosystem service information has yet to fundamentally change decision-making (Guerry et al., 2015, Ruckelshaus et al., 2015). On the other hand the growing evidence base does appear to be encouraging policy responses (for example the UK 2011 White Paper "The natural choice: securing the value of nature" response to the National Ecosystem Assessment, and the European Commission's Biodiversity Strategy commitments and related investments in the "Mapping and Assessment of Ecosystems and their Services" (MAES) initiative). Furthermore, valuation is only one aspect in a complex process and decision makers may have motives beyond the issues covered by valuation (Atkinson, 2015). This can even make policy makers reluctant to use CBA at policy formation stages, since the results might not support their favoured policies (Pearce, 1998), with formal tools coming into play only later via mandatory appraisals. Similarly, Mackie et al. (2014) argue that CBA often enters the planning process too late to play any meaningful role. This is particularly the case where planning processes are centred around a perceived "problem": where the problem is seen as central and significant, even inefficient solutions may be viewed as "better than nothing".

This situation reflects a number of barriers to take-up of economic valuation for decision making. Decision makers may focus on short-term more than long-term impacts, and may resist non-market valuation because it is perceived as less reliable than estimates of project costs (Barton, 2007) or market benefits. Formal appraisal tools (mostly CBA) are widely used, but often focus on direct costs to industry (Nilsson et al 2008). Although decision makers are increasingly aware of non-market costs and benefits, they often lack expertise or support needed to apply values in appraisals. Official guidelines such as the UK public sector "Green Book" (HMT, 2018 and supporting documents) help address this, though 
many countries lack guidelines. But even in the impact assessments of the UK Government, quantification and monetisation of ecosystem services remain rare: while carbon emissions and air pollution are commonly valued (following clear guidance), changes in the ecosystem services of climate regulation or air pollution regulation are less commonly reported or valued (eftec and Cascade, 2014). There is, as yet, no standardised approach for the private sector although this is changing, for example via the Natural Capital Committee publications (including the 'how to' guide) $)^{18}$, United Nations System of Environmental Economic Accounting (UN SEEA) guidelines ${ }^{19}$ and the Natural Capital Protocol ${ }^{20}$.

Although there remain gaps in the valuation evidence base, these are gradually being filled, and valuation databases such as EVRI and TEEB contain thousands of studies. ${ }^{21}$ As the number and impact of economic and environmental trade-offs are expected to grow, it is reasonable to expect continued theoretical development and application of robust and varied economic valuation technique in an increasingly diverse set of situations, as part of a broader policy analysis and decision support system (Turner, 2007). Wider use of economic valuation is occurring as a product of efforts to "mainstream" environmental concerns across all sectors. Researchers have recognised the challenges of communicating environmental priorities to policy makers in sectors that depend on and/or influence ecosystems, especially in the face of political agendas and private interests that have prioritised short-term growth and employment over longer-term concerns. They have responded with initiatives aiming to help ensure that environmental concerns are taken into account alongside economic and social priorities, leading to increasing use of economic valuation concepts in a wide range of policies and research initiatives at both national and international levels. For example, economic analysis was explicitly included in the EU Water Framework Directive (see eftec, 2010c). The Convention on Biological Diversity (CBD) Aichi Targets and the EU Biodiversity Strategy to 2020 (EUBS) both include targets and actions relating specifically to mainstreaming biodiversity values across government and society, promoting awareness of the economic

\footnotetext{
${ }^{18}$ https://www.gov.uk/government/groups/natural-capital-committee

${ }^{19}$ https://seea.un.org/

${ }^{20}$ https://naturalcapitalcoalition.org/

${ }^{21}$ www.evri.ca; https://www.es-partnership.org/services/data-knowledge-sharing/ecosystem-service-valuationdatabase/
} 
values of biodiversity and ecosystems, and incorporating these values in accounting and reporting systems. ${ }^{22}$

Meanwhile, work has advanced on natural capital accounting, in particular through the United Nations Statistics Division, the European Environment Agency and the World Bank Wealth Accounting and Valuation of Ecosystem Services (WAVES ${ }^{23}$ global partnership. The UN SEEA uses concepts, definitions and classifications consistent with the System of National Accounts (SNA) to facilitate integration of environmental and economic statistics, and is an international standard ${ }^{24}$. Full ecosystem accounting, including most accounting for biodiversity, comes under the SEEA Experimental Ecosystem Accounts, which is not (yet) a standard and is at the stage of further development and testing, e.g. in Europe (Weber, 2011) and the UK (ONS, 2018). Further moves to mainstreaming valuation are evident in the development of ISO 14007 and 14008 as noted above.

\section{Conclusion}

Monetary arguments for recognising the relative importance of different forms of natural capital and processes may not be to everyone's taste, but this framing can be useful and convincing for some decision makers. For others, initial mistrust of unfamiliar methods can give way to active demand for monetary evidence (e.g. Mathieu et al., 2016). Some reject monetary valuation "on principle" (e.g. McCauley, 2006), but, as Mace (2014) argues, "if the benefits provided by nature are assigned no value, they are treated as having no value, and current trends in the decline and deterioration of natural systems will continue." In her proposed "people and nature" framing for conservation, there is space for economic and monetary arguments alongside considerations of resilience, adaptability and the complex interdependencies of human and natural systems.

This flexibility can be central to keeping environmental issues in the mainstream of decision processes. For example, at the European level, the priority accorded to economic growth and employment under the Lisbon Strategy, coupled with the perception that

\footnotetext{
${ }^{22}$ Aichi targets 1 and 2, EUBS action 5.

${ }^{23}$ http://www.wavespartnership.org/en

${ }^{24}$ http://unstats.un.org/unsd/envaccounting/seea.asp
} 
environmental concerns are in opposition to growth, jobs and competitiveness, has created a serious challenge for environmental protection. In response, there has been growing emphasis on concepts such as the Circular Economy, Green Economy, green infrastructure, natural capital, and nature-based solutions, and a corresponding shift in language and arguments for environmental protection, with greater use of economic and monetary arguments for raising awareness and tracking performance (Tinch et al., 2015). At the launch of the 2020 biodiversity strategy, the European Parliament rapporteur stated 'each year we lose $3 \%$ of GDP due to the loss of biodiversity. That costs the EU $€ 450$ billion year after year. Compared to these figures, investing $€ 5.8$ billion per year in Natura 2000 is a bargain! ${ }^{25}$

Monetary valuation is not essential: there are alternative ways of carrying out appraisal (Multi criteria analysis, collective decision and other forms of deliberation methods), and even market-based instruments could be implemented without valuation. However, valuation can contribute to improving decisions, helping ensure that environmental concerns are taken fully into account on a "level playing field" with economic and social concerns, even in sectors not primarily focused on conservation.

Valuation is not a replacement for deliberation, but rather part of it, offering a particular way of examining the efficiency and distributional impacts of alternative uses of resources, and making deliberative processes easier, more efficient, and more transparent and replicable. In this light, it is encouraging to note the ongoing development of improved valuation methods and a richer evidence base, alongside growing private and public sector interest in incorporating natural capital and environmental flows in project appraisal and accounting processes.

\footnotetext{
${ }^{25}$ Gerben-Jan Gerbrandy (ALDE, NL). See http://ec.europa.eu/environment/nature/biodiversity/comm2006/2020.htm
} 


\section{References}

Abdalla C.W., Roach B.A. and Epp D.J. 1992. "Valuing environmental quality changes using averting expenditures: an application to groundwater contamination”. Land Economics 68(2):163-169

Adamowicz W., Louviere J., and Williams M. 1994. "Combining Revealed and Stated Preference Methods for Valuing Environmental Amenities". Journal of Environmental Economics and Management, 26, 271-292.

Allais, M. 1953. "Rational man's behavior in the presence of risk: Critique of the postulates and axioms of the American school". Econometrica, 21(4), 503-46.

Arrow, K. J. 1950. "A difficulty in the concept of social welfare". Journal of Political Economy, 58(4), 328-346.

Arrow, K.J., Cropper, M., Gollier, C., Groom, B., Heal, G.M., Newell, R.G., Nordhaus, W.D., Pindyck, R.S., Pizer, W.A., Portney, P. and Sterner, T., 2013. How should benefits and costs be discounted in an intergenerational context? The views of an expert panel. The views of an expert panel (December 19, 2013). Resources for the future discussion paper, (12-53).

Asplund, D., and Eliasson, J. 2016. "Does uncertainty make cost-benefit analyses pointless?" Transportation Research Part A: Policy and Practice, 92, 195-205.

Atkinson G., Morse-Jones S., Mourato S., and Provins A. 2012 " "When to take "No" for an answer'? Using entreaties to reduce protests in contingent valuation studies". Environmental and Resource Economics, 51, 497-523.

Atkinson, G. 2015. “Cost-Benefit Analysis: A Tool That Is Both Useful and Influential?”. The Tools of Policy Formulation, 142-160.

Atkinson, G., and Mourato, S. 2008. "Environmental cost-benefit analysis". Annual Review of Environment and Resources, v.33, pp. 317-44. 
Barberis, N., and Thaler, R. 2003. "A survey of behavioral finance". Handbook of the Economics of Finance, 1, 1053-1128.

Barbier E.B. 2007. "Valuing ecosystem services as productive inputs". Economic Policy, 22, 177-229.

Bartik T.J. 1988. "Evaluating the benefits of non-marginal reductions in pollution using information on defensive expenditures". Journal of Environmental Econonomics and Management, 15:111-127

Barton, D. 2007. How much is enough? The value of information from benefit transfers in a policy context. Environmental value transfer: Issues and methods, Springer: 261-282.

Bator, F. M. 1958. “The anatomy of market failure”. The Quarterly Journal of Economics, 72(3), 351-379.

Beaumont N.J., Hooper T., and Mongruel R. 2018. "Practical application of the Ecosystem Service Approach (ESA): Lessons learned and recommendations for the future". International Journal of Biodiversity Science, Ecosystem Services \& Management, $13: 3,68-78$

Bentham, Jeremy. 1789. An Introduction to the Principles of Morals and Legislation. London: T. Payne.

Boardman, A. E., Greenberg, D. H., Vining, A. R., and Weimer, D. L. 2017. Cost-benefit analysis: concepts and practice. Cambridge University Press.

Bockstael, N.E., Strand, I.E., and Hanemann, W.M. 1987. "Time and the recreational demand model". American Journal of Agricultural Economics, 69(2), 293-302.

Boulding, K.E. 1966. “The economics of the coming spaceship earth”. Environmental Quality Issues in a Growing Economy.

Bowe, C. and van der Horst D. 2015. "Positive externalities, knowledge exchange and corporate farm extension services; a case study on creating shared value in a water scarce area." Ecosystem Services 15: 1-10. 
Boxall P.C., Adamowicz W.L., Swait J., Williams M., and Louviere J. 1996. “A comparison of stated preference methods for environmental valuation". Ecological Economics, 18, 243-253.

Boyle, M. and Kiel, K. 2001. A survey of house price hedonic studies of the impact of environmental externalities. Journal of Real Estate Literature, 9(2), 117-144.

Braat L., ten Brink P. 2008. The cost of policy inaction - The case of not meeting the 2010 biodiversity target, Wageningen and Brussels.

Brander, L.M., Bräuer, I., Gerdes, H., Ghermandi, A., Kuik, O., Markandya, A., Navrud, S., Nunes, P.A., Schaafsma, M., Vos, H. and Wagtendonk, A., 2012. Using meta-analysis and GIS for value transfer and scaling up: Valuing climate change induced losses of European wetlands. Environmental and Resource Economics, 52(3), pp.395-413.

Brouwer, R., Langford, I.H., Bateman, I.J., and Turner, R.K. 1999. "A meta-analysis of wetland contingent valuation studies". Regional Environmental Change, 1(1), 47-57.

Brown W.G., Nawas F. 1973. "Impact of Aggregation on the Estimation of Outdoor Recreation Demand Functions". American Journal of Agricultural Economics, 55, 246-249.

Brown, T.C., and Gregory, R. 1999. "Why the WTA-WTP disparity matters". Ecological Economics, 28(3), 323-335.

Cardinale, B.J., Duffy, J.E., Gonzalez, A., Hooper, D.U., Perrings, C., Venail, P., Narwani, A., Mace, G.M., Tilman, D., Wardle, D.A. and Kinzig, A.P., 2012. Biodiversity loss and its impact on humanity. Nature, 486(7401), p.59.

Carson R.T., and Groves T. 2007. "Incentive and informational properties of preference questions". Environmental and Resource Economics, 37, 181-210.

Carson R.T., Hanemann W.M. 2005. “Contingent valuation”. In: Mäler K.-G. Vincent J.R. (eds.) Handbook of Environmental Economics, Elsevier, 821-936 
Chien Y.-L., Huang C.J., and Shaw D. 2005. "A general model of starting point bias in DBDC CV surveys". Journal of Environmental Economics and Management, 50, 362377.

Chiesura, A., and De Groot, R. 2003. "Critical natural capital: a socio-cultural perspective”. Ecological Economics, 44(2-3), 219-231.

Clawson M. 1959. Methods of measuring the demand for and value of outdoor recreation, Resources for the future, Washington.

Clawson M., and Knetsch J.L. 1966. Economics of outdoor recreation. John Hopkins University Press, Baltimore.

Colander, D., Goldberg, M., Haas, A., Juselius, K., Kirman, A., Lux, T. and Sloth, B., 2009. The financial crisis and the systemic failure of the economics profession. Critical Review, 21(2-3), pp.249-267.

Costanza, R., d'Arge, R., De Groot, R., Farber, S., Grasso, M., Hannon, B., Limburg, K., Naeem, S., O'neill, R.V., Paruelo, J. and Raskin, R.G., 1997. The value of the world's ecosystem services and natural capital. Nature, 387(6630), p.253.

Costanza, R., de Groot, R., Sutton, P., Van der Ploeg, S., Anderson, S.J., Kubiszewski, I., Farber, S. and Turner, R.K., 2014. Changes in the global value of ecosystem services. Global Environmental Change, 26, pp.152-158.

Costanza, R., de Groot, R., Braat, L., Kubiszewski, I., Fioramonti, L., Sutton, P., and Grasso, M. 2017. Twenty years of ecosystem services: how far have we come and how far do we still need to go?. Ecosystem Services, 28, 1-16.

Courant P.N. and Porter R.C. 1981. Averting expenditure and the cost of pollution. Journal of Environmental Economics and Management 8(4):321-329.

Cummings R.G., and Taylor L.O. 1999. "Unbiased value estimates for environmental goods: A cheap talk design for the contingent valuation method". The American Economic Review, 89, 649-665. 
Cummings R.G., Brookshire D.S., and Schulze W.D. 1986. Valuing environmental goods. An assessment of the contingent valuation method. Rowman \& Littlefield, Savage.

Curnow J. 2019. "Environmental Economics in UK Environmental Policy: Defra's 25 Year Environment Plan and Others", Journal of Environmental Economics and Policy, this issue.

Czembrowski, P. and Kronenberg, J. 2016. Hedonic pricing and different urban green space types and sizes: Insights into the discussion on valuing ecosystem services. Landscape and Urban Planning, 146, 11-19.

Daly, H.E. 1973. Toward a steady-state economy. San Francisco, CA: Freeman, 1973.

d'Aspremont, C., and Gevers, L. 2002. "Social welfare functionals and interpersonal comparability". Handbook of Social Choice and Welfare, 1, 459-541.

Davis R.K. 1963. The value of outdoor recreation: An economic study of the Maine woods. Harvard University.

Day, B., Bateman, I. and Lake, I. 2007. Beyond implicit prices: recovering theoretically consistent and transferable values for noise avoidance from a hedonic property price model. Environmental and Resource Economics, 37(1), 211-232.

Day, B., Bateman, I.J., Carson, R.T., Dupont, D., Louviere, J.J., Morimoto, S., Scarpa, R. and Wang, P., 2012. Ordering effects and choice set awareness in repeat-response stated preference studies. Journal of Environmental Economics and Management, 63(1), pp.73-91.

De Groot, R., Brander, L., Van Der Ploeg, S., Costanza, R., Bernard, F., Braat, L., Christie, M., Crossman, N., Ghermandi, A., Hein, L. and Hussain, S., 2012. Global estimates of the value of ecosystems and their services in monetary units. Ecosystem Services, 1(1), pp.50-61.

Díaz, S., Pascual, U., Stenseke, M., Martín-López, B., Watson, R.T., Molnár, Z., Hill, R., Chan, K.M., Baste, I.A., Brauman, K.A. and Polasky, S., 2018. Assessing nature's contributions to people. Science, 359(6373), pp.270-272. 
Dickie, I. and Neupauer, S. 2019. Natural Capital Accounts: nations and organisations, Journal of Environmental Economics and Policy, this issue - detailed TBC

eftec and Cascade 2014. "Baseline evaluation of environmental appraisal and sustainable development guidance across government”. Defra.

eftec. 2010. "Valuing environmental impacts: practical guidelines for the use of value transfer in policy and project appraisal". Report to Defra.

https://www.gov.uk/government/publications/valuing-environmental-impactsguidelines-for-the-use-of-value-transfer

eftec. 2010b. "Benefits and costs of conserving biodiversity and ecosystem services". Final Report to the European Commission, DG Environment.

ENV/07.0307/2009/553444/ETU/B2.

eftec. 2010c. "Scoping study on the economic (or non-market) valuation issues and the implementation of the Water Framework Directive". Final report to the European Commission. ENV.D.1/ETU/2009/0102rI

EPA .2010. "Guidelines for preparing economic analyses" https://www.epa.gov/environmental-economics/guidelines-preparing-economicanalyses

European Commission. 2015. "Guide to Cost-Benefit Analysis of Investment Projects Economic appraisal tool for Cohesion Policy 2014-2020" http://ec.europa.eu/regional_policy/sources/docgener/studies/pdf/cba_guide.pdf

Faber, M. 2008. "How to be an ecological economist”. Ecological Economics 66(1):1-7.

Faccioli, M., Hanley, N., Torres, C., and Font, A.R. 2016. "Do we care about sustainability? An analysis of time sensitivity of social preferences under environmental timepersistent effects”. Journal of Environmental Management, 177, 356-364.

Faccioli, M., Kuhfuss, L., and Czajkowski, M. 2018. "Stated Preferences for Conservation Policies Under Uncertainty: Insights on the Effect of Individuals' Risk Attitudes in the 
Environmental Domain". Environmental and Resource Economics, https://doi.org/10.1007/s10640-018-0276-2

Fifer S., Rose J., Greaves S. 2014. "Hypothetical bias in stated choice experiments: Is it a problem? And if so, how do we deal with it?" Transportation Research Part A: Policy and Practice, 61, 164-177.

Fisher, B., Turner, R.K. and Morling, P., 2009. Defining and classifying ecosystem services for decision making. Ecological Economics, 68(3), pp.643-653.

Flyvbjerg, B. 2009. "Survival of the unfittest: why the worst infrastructure gets built - and what we can do about it". Oxford Review of Economic Policy, 25(3), 344-367.

Freeman, A. M. 1981. Hedonic prices, property values and measuring environmental benefits: a survey of the issues. In Measurement in Public Choice (pp. 13-32). Palgrave Macmillan, London.

Friedman, M 1953. "The methodology of positive economics". In Essays in Positive Economics, Chicago Press.

Gómez-Baggethun, E. and D.N. Barton. 2013. "Classifying and valuing ecosystem services for urban planning." Ecological Economics 86: 235-245.

Gómez-Baggethun, E., De Groot, R., Lomas, P.L., and Montes, C. 2010. “The history of ecosystem services in economic theory and practice: from early notions to markets and payment schemes". Ecological Economics, 69(6), 1209-1218.

Groffman, P.M., Baron, J.S., ... and Poff, N.L. 2006. "Ecological thresholds: the key to successful environmental management or an important concept with no practical application?" Ecosystems, 9(1), 1-13.

Guerry, A.D., Polasky, S., Lubchenco, J., Chaplin-Kramer, R., Daily, G.C., Griffin, R., Ruckelshaus, M., Bateman, I.J., Duraiappah, A., Elmqvist, T. and Feldman, M.W., 2015. Natural capital and ecosystem services informing decisions: From promise to practice. Proceedings of the National Academy of Sciences, 112(24), pp.7348-7355 
Gum R.L., and Martin W.E. 1975. "Problems and Solutions in Estimating the Demand for and Value of Rural Outdoor Recreation". American Journal of Agricultural Economics, $57,558-566$.

Hanemann W.M. 1991. "Willingness to pay and willingness to accept: How much can they differ?" The American Economic Review, 81, 635-647.

Hanley N., Wright R.E., and Adamowicz V. 1998. "Using choice experiments to value the environment". Environmental and Resource Economics, 11(3-4), 413-428.

Hausman J. 2012. "Contingent valuation: From dubious to hopeless". Journal of Economic Perspectives, 26, 43-56.

Heal, G.M. and Millner, A. 2014. "Agreeing to disagree on climate policy”. PNAS 2014, $111: 10,3695-3698$

Hicks J.R. 1943. “The four consumer's surpluses”. Review of Economic Studies, 11, 31-41.

Hicks, J.R. 1939. “The foundations of welfare economics”. The Economic Journal, 49(196), 696-712.

Hite, D., Chern, W., Hitzhusen, F., and Randall, A. 2001. Property-value impacts of an environmental disamenity: the case of landfills. The Journal of Real Estate Finance and Economics, 22(2-3), 185-202.

HMT 2018. "The Green Book: Appraisal and evaluation in central government" https://www.gov.uk/government/publications/the-green-book-appraisal-andevaluation-in-central-governent

Hoch, S.J., and Loewenstein, G.F. 1991. "Time-inconsistent preferences and consumer selfcontrol'. Journal of Consumer Research, 17(4), 492-507

Hochman, H.M., and Rodgers, J.D. 1969. "Pareto optimal redistribution". The American Economic Review, 59(4), 542-557.

Horowitz J.K., and McConnell K.E. 2002. “A review of WTA/WTP studies”. Journal of Environmental Economics and Management, 44, 426-447. 
Hotelling, H. 1947. "The economics of public recreation”. The Prewitt Report.

Hoyos D. 2010. "The state of the art of environmental valuation with discrete choice experiments". Ecological Economics, 69, 1595-1603.

Hume, D. 1751. An Enquiry Concerning the Principles of Morals. London: A. Millar.

Illge, L. and Schwarze, R. 2006. "A Matter of Opinion: How Ecological and Neoclassical Environmental Economists Think about Sustainability and Economics”. German Institute for Economic Research.

Irvine, K.A., O’Brien, L., Ravenscroft, N., Cooper, N., Everard, M., Fazey, I., Reed, M.S. and Kenter, J.O. 2016. Ecosystem services and the idea of shared values. Ecosystem Services 21: 184-193 http://dx.doi.org/10.1016/j.ecoser.2016.07.001

Johnston, R.J., Boyle, K.J., Adamowicz, W., Bennett, J., Brouwer, R., Cameron, T.A., Hanemann, W.M., Hanley, N., Ryan, M., Scarpa, R. and Tourangeau, R., 2017. Contemporary guidance for stated preference studies. Journal of the Association of Environmental and Resource Economists, 4(2), pp.319-405.

Jorgensen B.S., Syme G.J., Bishop B.J., and Nancarrow B.E. 1999. "Protest responses in contingent valuation”. Environmental and Resource Economics, 14, 131-150.

Kahneman D. and Tversky, A. 1979. "Prospect Theory: An Analysis of Decision under Risk". Econometrica 47 (2): 263-91.

Kenter, J.O., O'Brien, L., Hockley, N., Ravenscroft, N., Fazey, I., Irvine, K.N., Reed, M.S., Christie, M., Brady, E., Bryce, R., Church, A., Cooper, N., Davies, A., Evely, A., Everard, M., Fish, R., Fisher, J.A., Jobstvogt, N., Molloy, C., Orchard-Webb, J., Ranger, S., Ryan, M., Watson, V. and Williams, S. 2015. What are shared and social values of ecosystems? Ecological Economics 111 (2015) 86-99. doi:10.1016/j.ecolecon.2015.01.006

Kirby, K.N. 1997. "Bidding on the future: evidence against normative discounting of delayed rewards". Journal of Experimental Psychology: General, 1261, 54-70. 
Kling C.L., Phaneuf D.J., and Zhao J. 2012. "From Exxon to BP: Has some number become better than no number?" Journal of Economic Perspectives, 26, 3-26.

Koshy A., Raynaud J., Ozdemiroglu, E. and Provins A.2019. Natural Capital Statements: A Case Study on SCA, a Swedish paper and pulp company, Journal of Environmental Economics and Policy, this issue.

Kosoy, N., and Corbera, E. 2010. "Payments for ecosystem services as commodity fetishism". Ecological Economics, 69(6), 1228-1236.

Kremen, C. 2005. "Managing ecosystem services: what do we need to know about their ecology?” Ecology Letters, 8(5), 468-479.

Laurans, Y., Rankovic A, Billé R, Pirard R, and Mermet L. 2013. "Use of ecosystem services economic valuation for decision making: questioning a literature blindspot." Journal of Environmental Management 119: 208-219.

Laville, F. 2000. "Foundations of procedural rationality: cognitive limits and decision processes.” Economics \& Philosophy, 16(1), 117-138.

Laville, F. 2000. "Should we abandon optimization theory? The need for bounded rationality". Journal of Economic Methodology, 7(3), 395-426.

Lichtenstein, S. and Slovic, P. 1971. "Reversals of preference between bids and choices in gambling decisions2. Journal of Experimental Psychology, 89(1), 46.

Little J., and Berrens R. 2004. "Explaining disparities between actual and hypothetical stated values: Further investigation using meta-analysis”. Economics Bulletin, 3, 1-13.

Liu, J. T., Hammitt, J. K. and Liu, J. L. 1997. Estimated hedonic wage function and value of life in a developing country. Economics Letters, 57(3), 353-358.

Lloyd-Smith, P., Schram, C., Adamowicz, W. and Dupont, D. (2018). Endogeneity of risk perceptions in averting behavior models. Environmental and Resource Economics, 69(2), 217-246. 
Loomes G., and Sugden R. 1982. "Regret Theory: An alternative theory of rational choice under uncertainty". The Economic Journal, 92, 805-824.

MA. 2005. Millennium Ecosystem Assessment. Ecosystems and human well-being: A framework for assessment. Island Press, Washington DC.

Mackie, P., and Preston, J. 1998. "Twenty-one sources of error and bias in transport project appraisal”. Transport Policy, 5(1), 1-7.

Mackie, P., Worsley, T., and Eliasson, J. 2014. “Transport appraisal revisited". Research in Transportation Economics, 47, 3-18.

Malthus, T.R. 1853. Definitions in political economy. Simpkin and Marshall, London.

March, J.G., and Simon, H.A. 1958. "Cognitive limits on rationality”. Organizations, 136171.

Marx, K. 1887. "Capital Volume 1. The process of production of capital”. In Tucker R.C. The Marx-Engels reader. W.W. Norton and company, London

Mathieu L, Tinch R, and Provins A. 2016. "Catchment management in England and Wales: the role of arguments for ecosystems and their services". Biodiversity Conservation. 27:7, pp 1639-1658

McCauley, D.J. 2006. "Selling out on nature”. Nature, 443(7107), 27.

Meadows, D.H., Meadows, D.L., Randers, J., and Behrens, W.W. 1972. "The limits to growth”. New York, 102, 27.

Meyerhoff J., and Liebe U. 2006. "Protest beliefs in contingent valuation: Explaining their motivation". Ecological Economics, 57, 583-594.

Meyerhoff J., and Liebe U. 2010. "Determinants of protest responses in environmental valuation: A meta-study”. Ecological Economics, 70, 366-374. 
Miao, W., Huang, X., and Song, Y. 2017. "An economic assessment of the health effects and crop yield losses caused by air pollution in mainland China". Journal of Environmental Sciences, 56, 102-113.

Mitchell R.C, and Carson R.T. 1989. "Using surveys to value public goods: The contingent valuation method". Resources for the Future, Washington.

Muradian, R. 2001. Ecological thresholds: a survey”. Ecological Economics, 38(1), 7-24.

Neumann, J von., and Morgenstern, O. 1953[1944]. Theory of games and economic behavior. (Third ed.). Princeton, NJ: Princeton University Press

Nilsson, M., Jordan, A., Turnpenny, J., Hertin, J., Nykvist, B., and Russel, D. 2008. "The use and non-use of policy appraisal tools in public policy making: an analysis of three European countries and the European Union”. Policy Sciences, 41(4), 335-355.

Nordhaus W.D. 1992. "An Optimal Transition Path for Controlling Greenhouse Gases". Science. 258 (5086): 1315-1319.

Nordhaus, W.D. 1993. "Rolling the 'DICE': an optimal transition path for controlling greenhouse gases." Resource and Energy Economics, 15(1), 27-50

OECD 2018. Cost-Benefit Analysis and the Environment: Further Developments and Policy Use, OECD Publishing, Paris, https://doi.org/10.1787/9789264085169-en

ONS. 2018. "UK Natural Capital: interim review and revised 2020 roadmap" https://www.ons.gov.uk/economy/nationalaccounts/uksectoraccounts/methodologies/u knaturalcapitalinterimreviewandrevised2020roadmap

Ozdemiroglu E. 2019. Journal of Environmental Economics and Policy, this issue.

Ozdemiroglu E. and R. Hails (eds) 2016. Demystifying Economic Valuation, Valuing Nature Paper. http://valuing-nature.net/demystifying-economic-valuation-paper

Pareto., V. 1906. Manual of Political Economy. 
Parks, S., and Gowdy, J. 2013. "What have economists learned about valuing nature? A review essay". Ecosystem Services, 3, e1-e10.

Pascual, U., Termansen, M., Hedlund, K., Brussaard, L., Faber, J.H., Foudi, S., Lemanceau, P. and Jørgensen, S.L., 2015. On the value of soil biodiversity and ecosystem services. Ecosystem Services, 15, pp.11-18.

Pearce, D. 1998. "Cost benefit analysis and environmental policy". Oxford Review of Economic Policy, 14(4), 84-100.

Pearce, D. 2002. “An intellectual history of environmental economics”. Annual Review of Energy and the Environment, 27(1), 57-81.

Pearce, David. W., Anil Markandya and Edward B. Barbier. 1989. Blueprint for a green economy. Earthscan, 1989

Petty, Sir William. 1899 [1664] Verbum Sapienti, The Economic Writings of Sir William Petty, ed. C.H. Hull, Cambridge: Cambridge University Press.

Phaneuf, D.J., and Smith, V.K. 2005. "Recreation demand models". Handbook of Environmental Economics, 2, 671-761.

Pigou, A.C. 1920. The economics of welfare.

Powe N.A., and Bateman I.J. 2003. 'Ordering effects in nested 'top-down' and 'bottom-up' contingent valuation designs". Ecological Economics, 45, 255-270.

Powe N.A., and Bateman I.J. 2004. "Investigating insensitivity to scope: A split-sample test of perceived scheme realism". Land Economics, 80, 258-271.

Randall A., Ives B., and Eastman C. 1974. "Bidding games for valuation of aesthetic environmental improvements". Journal of Environmental Economics and Management, 1, 132-149.

Ravenscroft, N. 2010. 'The mythologies of environmental economics'. Journal of Policy Research in Tourism, Leisure and Events 2(2): 129-143. 
Ravenscroft, N. 2019. A new normative economics for the formation of shared values.

Sustainability Science DOI: 10.1007/s11625-018-0652-4

Raworth, K. 2018. Doughnut Economics: Seven Ways to think like a $21^{\text {st }}$ Century Economist. London: Random House. 372 pp,

Ridker R.G. 1967. Economic costs of air pollution: Studies in measurement, New York.

Rode, J., Gómez-Baggethun, E., and Krause, T. 2015. "Motivation crowding by economic incentives in conservation policy: A review of the empirical evidence". Ecological Economics, 117, 270-282.

Rosen, S. "Hedonic Prices and Implicit Markets: Product Differentiation in Pure Competition.” Journal of Political Economy. Vol. 82. Issue 1. 1974. pp 34-55

Ruckelshaus, M., McKenzie, E., Tallis, H., Guerry, A., Daily, G., Kareiva, P., Polasky, S., Ricketts, T., Bhagabati, N., Wood, S.A. and Bernhardt, J., 2015. Notes from the field: lessons learned from using ecosystem service approaches to inform real-world decisions. Ecological Economics, 115, pp.11-21.

Saez, C.A., and Requena, J.C. 2007. "Reconciling sustainability and discounting in CostBenefit Analysis: A methodological proposal”. Ecological Economics, 60(4), 712-725.

Schmidt, S., Manceur, A. M. and Seppelt, R. 2016. Uncertainty of monetary valued ecosystem services-value transfer functions for global mapping. PloS one, 11(3), e0148524.

Slovic, P. 1995. “The construction of preference”. American Psychologist, 50(5), 364.

Smith, V. K. and Huang, J. C. 1993. Hedonic models and air pollution: twenty-five years and counting. Environmental and Resource Economics, 3(4), 381-394.

Stern, N., and Taylor, C. 2007. "Climate change: Risk, ethics, and the Stern review". Science, 317(5835), 203-204. 
Stern, N., Peters, S., Bakhshi, V., Bowen, A., Cameron, C., Catovsky, S., Crane, D., Cruickshank, S., Dietz, S., Edmondson, N. and Garbett, S., 2006. The economics of climate change. Cabinet Office-HM Treasury.

Stiglitz, J.E. 1987. "Pareto efficient and optimal taxation and the new new welfare economics". In Handbook of Public Economics (Vol. 2, pp. 991-1042). Elsevier.

Sullivan, S. 2013. "Banking nature? The spectacular financialisation of environmental conservation". Antipode, 45(1), 198-217.

Taleb, N.N., Read, R., Douady, R., Norman, J. and Bar-Yam, Y. 2014. The Precautionary Principle (with Application to the Genetic Modification of Organisms), Extreme Risk Initiative - NYU School of Engineering Working Paper Series.

Tansley, A.G. 1935: The use and abuse of vegetational concepts and terms. Ecology 16, 284 307

TEEB. 2010. The Economics of Ecosystems and Biodiversity: Ecological and Economic Foundations. Earthscan, London and Washington.

Thaler R. 2015. Misbehaving: The Making of Behavioral Economics. New York: W. W. Norton.

Thaler R. and C. Sunstein. 2008. Nudge: Improving Decisions about Health, Wealth, and Happiness, New Haven, CT: Yale University Press.

Tinch Robert. 2018. "Debating Nature's Value: The role of monetary valuation". Ch5 in Anderson, V (ed) Debating Nature's Value: The Concept of Natural Capital. Palgrave.

Tinch, R, Schoumacher, C and van den Hove, S. 2015. "Exploring barriers to integration of biodiversity concerns across EU policy." in Gasparatos, A., \& Willis, K. J. (eds.). Biodiversity in the Green Economy. Routledge.

Tinch, R., Bugter, R., Blicharska, M., Harrison, P., Haslett, J., Jokinen, P., Mathieu, L. and Primmer, E., 2018. Arguments for biodiversity conservation: factors influencing their 
observed effectiveness in European case studies. Biodiversity and Conservation, 27(7), pp.1763-1788.

Turner, R.K. 2007. "Limits to CBA in UK and European environmental policy: retrospects and future prospects". Environmental and Resource Economics, 37(1), 253-269.

Tversky, A., and Kahneman, D. 1991. "Loss aversion in riskless choice: A referencedependent model”. The Quarterly Journal of Economics, 106(4), 1039-1061.

United Kingdom National Economic Assessment Follow On. 2014.

United Kingdom National Ecosystem Assessment. 2011.

van den Bergh, J.C.J.M. 2001. "Ecological Economics: Themes, Approaches, and Differences with Environmental Economics," Regional Environmental Change, 2(1), pp. 13-23.

Vatn, A. 2000. "The environment as a commodity". Environmental Values, 9(4), 493-509.

Veisten K., Hoena H.F., Navrud S., and Strand J. 2004. "Scope insensitivity in contingent valuation of complex environmental amenities". Journal of Environmental Management, 73, 317-331.

Venkatachalam L. 2004. "The contingent valuation method: A Review”. Environmental Impact Assessment Review, 24, 89-124.

Wales, A. 2014. "Making sustainable beer." Nature Climate Change 4(5): 316-318.

Walras, Léon 1954 [1877]. Elements of Pure Economics. Irwin. ISBN 0-678-06028-2.

Ward F.A., and Beal D. 2000. "Valuing nature with travel cost models. A manual". Edward Elgar, Cheltenham.

Weber, J.L. 2011. “An experimental framework for ecosystem capital accounting in Europe”. European Environment Agency, Technical report 13.

Weitzman, M. L. 2001. "Gamma discounting." American Economic Review 91(No.1): 260-271. 
Weitzman, M.L. 2009. On Modeling and Interpreting the Economics of Catastrophic Climate Change. The Review of Economics and Statistics, XCI:1. Harvard University, USA. Available at this address:

http://scholar.harvard.edu/files/weitzman/files/modelinginterpretingeconomics.pdf

Weitzman, M.L. 2007. "A review of the Stern Review on the economics of climate change". Journal of Economic Literature, 45:3, 703-724.

Whynes D.K., Wolstenholme J.L., and Frew E. 2004. "Evidence of range bias in contingent valuation payment scales". Health Economics, 13, 183-190. 


\section{Figures}

Figure 1: The Total Economic Value framework

Source: adapted from Pascual et al., 2015. 